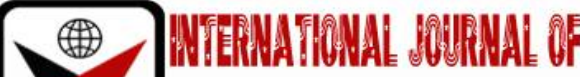

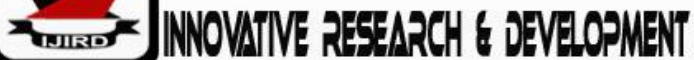

ISSN 2278 - 0211 (Online)

\section{The Effect of Creative Accounting on the Financial Performance of Deposit Money Banks in Nigeria from 2008 -2017}

Ehiriudu, Jude Alaoma
Lecturer, Department of Accountancy, Institute of Management and Technology (IMT), Nigeria
Ude, George Iweka
Lecturer, Department of Accountancy, Institute of Management and Technology (IMT), Nigeria
Ani, Michael Uchenna
Lecturer, Department of Accountancy, Institute of Management and Technology (IMT), Nigeria

\begin{abstract}
:
The study examines effect of creative accounting on the financial performance of deposit money banks in Nigeria from 2008-2017. The following money banks were used Diamond bank, First bank, Zenth bank, United Bank for Africa (UBA), Guaranty Trust Bank. The dependent variable is profit after tax (PAT) and Independent variable includes; total assets, total liabilities and total equity. The researcher adopted ex-post fact research design. A panel data gotten from fact book of CBN covering the of 10years from deposit money banks were analyzed using descriptive statistics, unit root test and multiple regression analysis. The study revealed that creative accounting in assets has a positive and significant effect on the profit after tax of deposit money banks in Nigeria. The research concluded that creative accounting in Assets, Liabilities and Equities has a positive and significant effect on the profit after tax of deposit money banks in Nigeria.
\end{abstract}

Keywords: Assets, liabilities, equities and profit after tax

\section{Introduction}

\subsection{Background of the Study}

Creative accounting or window dressing accounting consists of accounting practices that follow required laws and regulations, but deviate from what those standards intends to accomplish (Gherai and Balaciu, 2011). The term creative accounting was first used in 1968 in the film, "The Produce", by Mel Brooks (Idris, Kehinde, Ajemunigbohun and Gabriel, 2012). According to them when no fraud is involved, creative accounting, in its strict sense, involves the transformation of financial accounts using accounting choices, estimates and other practices allowed by accounting regulations. It appeared in the Anglo-Saxon literature in the 1970s, most often in the papers about the bankruptcy of enterprises and those written by Watts and Zimmerman,(1978) which represent the foundation of the positive accounting theory (Ezeani, 2010).

Leyira and Okeoma (2014) state that creative accounting describes the process through which the accounting professionals use their knowledge in order to manipulate the figures included in the annual accounts.

Financial statements are the mirror of every company's business. They also represent a medium through which information on the financial position and business success of a company are communicated, primarily to external interest groups, which make different decisions based on such information. In order to be able to make the right decisions, the information contained in financial statements must be accurate and reliable. However, companies nowadays are increasingly resorting to "cooking" financial statements in order to present a more attractive business image and attract as many investors as possible (Healy and Wahlen, 1999). This is precisely why the concept of creative accounting has appeared. In other words, there is a distortion of financial information and presumptions of accuracy and reliability are brought into question.

Hall (2005) states that increasing competition and the economic environment are just some of the reasons why companies resort to various accounting manipulation techniques, with the aim of concealing possible losses and presenting the business in the best possible light. This does not necessarily mean that there is violation of accounting standards and legal regulations, but the so-called "loopholes" in laws are used to present a better image of the business. It should be noted that the practice of creative accounting is not illegal - which is why auditors often neglect it, but these are unethical procedures.

Idris, Kehinde, Ajemunigbohun and Gabriel (2012) note that creative accounting consists of accounting practices that follow required laws and regulations, but deviate from what those standards intend to accomplish. Creative 
accounting capitalizes on loopholes in the accounting standards to falsely portray a better image of the company. Although creative accounting practices are legal, the loopholes they exploit are often reformed to prevent such behaviors.

Companies' management may adopt various methods to dress up financial statement to show improved performance in respect of profit or loss. For the balance sheet, it may exist in three areas: the incorrect valuation of companies' assets, accounting for all liabilities and over or under-statement of net worth. The effect of creative accounting may defeat the purpose of presentation of true and fair financial statement, as required by Companies and Allied Matters Act (CAMA) (Leyira and Okeoma, 2014).

A typical aim of creative accounting is to inflate profit figure. However, some companies also reduce reported profit in good years to smooth result. Assets and liabilities may also be manipulated, either to remain within limits such as debt covenant, or to hide problems. Leyira and Okeoma (2014) assert that typical creative accounting tricks include off balance sheet financing, over-optimistic revenue recognition and the use of exaggerated non- recurring items. Every organization desires to achieve its goals, objectives or intended performance of continuous steady growth in profit, increase share prices by attracting more investors so as to get a larger share of their target market and increased productivity. Creative accounting seems to be a readily available tool in the hands of many preparers of financial statements to dress up its financial statements to achieve effectiveness. Studies have revealed that company managers willfully manipulate reported profit to fit their own intentions or goals by selecting certain policies changing accounting estimates and manipulating accruals (Yoon and Miller, 2002). About the importance of financial reporting, Akenbor and Ibanichuka (2012) had highlighted many points. Leyira and Okeoma (2014) opine that if organizations are to survive and achieve long-term viability, they must be effective. Friedlander and Pickle (1968) are of the view that an effective organization is one that is making profit in addition to other criteria. Imoisili (1978) included increase in market share as one of the evidence of organizational effectiveness. Shareholders require good returns on their investment and this cannot be achieved when a company is not profitable. Thus, a profitable firm is an effective organization. Effectiveness of organizations and its performance has been highlighted by Richard, Devinney, Yip and Johnson (2009). This views also help in economic valuation. Deposit money banks are the most important savings mobilizing and financial resource allocation institutions. Consequently, their roles make them an important phenomenon and strong pillar in economic growth and development. Deposit money banks which are also known as commercial banks are financial institutions that provide services, such as accepting deposits, giving business loans and auto loans, mortgage lending, and basic investment products like savings accounts and certificates of activities deposit (Uzonwanne, 2015).

According to mainstream theory, they act as financial intermediaries to channel savers' money to firms and individuals who seek funding for their acts. Their importance as a catalyst to economic growth/development is widely recognized by both monetary and development economists. The financial system of Nigeria is dominated by the banking sector, especially the deposit money bank which provides the foundation for the development of financial system. Their credit component constitutes a major link between the monetary sector and the real sector of the Nigerian economy. In performing these roles, deposit money banks must realized that they have the potentials, scopes and prospects of mobilizing financial resources and allocating them to productive investments and, in return, promote sustainable performance and ensures that businesses are flourishing and alive. They not only store our saved cash and lend us money when we need it, but act as the system of arteries that transport money around the economy, that is why they are often known as financial intermediaries. Hence their key function is to transfer money, en masse, from those who want to lend to those who want to borrow.

\subsection{Statement of the Problem}

Sen and Inanga (2004); Amat, Blake and Dowds (1999), have highlighted the importance of price manipulation, profit overstatement, and accounts. How financial performance gets affected by the creative accounting has been focused by Sen and Inanga (2004). Even from the UK, Spain and New Zealand perspective Amat, Blake and Dowds (1999) had also highlighted the importance of creative accounting. Even environmental differences have also been highlighted by these authors. From Nigerian perspective, Leyira and Okeoma (2014) and Modum, Ugwoke, Onyeanu, Modebe, Kodjo \& Odoh, (2014), had conducted many studies. A prominent gap exists in Nigerian perspective to find out the effect of creative accounting practices.

\subsection{Objectives of the Study}

To study the effect of creative accounting on the financial performance for deposit money banks in Nigeria from 2008 to 2017 is the main objective of this study. Other objectives are as follows:

- To study how creative accounting in assets affect the profit after tax.

- The degree up to which creative accounting in liabilities affect the profit after tax.

- Examine the relationship between creative accounting in equity and profit after tax.

\subsection{Research Hypotheses}

The following null hypotheses are for the study:

- $\mathrm{H}_{01}$ : In case of Nigerian deposit banks, creative accounting in assets does not have positive and significant effect.

- $\mathrm{H}_{02}$ : In case of Nigerian deposit banks, creative accounting in liabilities does not positively and significantly affect the profit after tax.

- $\mathrm{H}_{03}$ : In case of Nigerian deposit banks, a significant relationship does not exist between creative accounting in equity and profit after tax. 


\subsection{Significance of the Study}

The study will be of immense significance to the following groups of people:

\subsubsection{Nigerian Deposit Money Banks}

The study will be of immense benefit to deposit money banks in Nigeria in that it will further enlighten them on the concept of creative accounting, how it can ruin the corporate image of the banking sector as well as the financial system, since this sector dominates the financial system, when a falsified financial statement is presented to the public.

\subsubsection{Shareholders and Bank Customers}

The study will enlighten shareholders and customers of deposit money banks in Nigeria on how some banks have been able to falsify their financial statement to elevate the digits to what does not exist thereby deceiving investors.

\subsubsection{Government/Policy Makers}

The recommendations of the study will suggest for the government or policy makers on the best approaches to checkmate the financial activities of deposit money banks in Nigeria to either eliminate totally or reduce to the barest minimum the falsification of financial statement as it affects investors' decisions.

\subsubsection{Academia/Researchers}

The study will contribute to existing literature and will be of immense benefit to students and other researchers who will utilize the information contained in this study for their own research works.

\subsection{Scope of the Study}

Our study on the effect of creative accounting on the financial performance of deposit money banks in Nigeria from 2008 to 2017. The following banks were covered in this study; Diamond Bank Plc, First Bank Plc, Zenith Bank Plc, United Bank for Africa (UBA) and Access Bank Plc. The base year of 2008 was selected due to the 2008/2009 financial crash in Nigeria which emanated from the ripple effect of the 2007/2008 global financial crisis while the basis for the selection of the banks rests on the fact that these banks have been rated as the top most five Nigerian banks by Fitch rating and Bankers' magazine as at January 2017.

\section{Review of Related Literature}

\subsection{Conceptual Review}

\subsubsection{Concept of Creative Accounting}

Under three different financial market conditions, Akenbor and Ibanichuka (2012) had mentioned about the importance of creativity. The first is when a company floats its shares to attract investors to subscribe to such shares either at par or at a premium. The second is when the company whose shares are already listed in a stock exchange, wants to paint an attractive picture of its financial conditions so that the shares may be quoted at a premium. Changes of economic, social, political and business environments can be highlighted by creative accounting. But, it has many side effects like deceptive accounting or window dressing accounting. This is the reason why two thoughts lie. Financial accounting reports are fashioned to illustrate the accurate and blond state of financial statements of a body in order to help stakeholders in making appropriate decisions (Beshiru and Prince, 2014). Accounting arose from the need to have a clear situation of everything happening economically and financially in a company, which offered at the beginning prestige and trust of users of accounting information, however over time, more and more scandals that erupted because of infringement of regulations (Voinea, 2013). The phenomenon of creative accounting can be understood as the alteration of the economic reality of an entity through techniques, options, lack of restraints allowed by the legal norms (Radu, 2013). The creative accounting is a tool to support the manager to promote and support the company's image; however, the manager used that information to support his self interest (Victoria, 2014).

The techniques of creative accounting can be used in an unacceptable way in the preparation of the financial statements in order to meet management needs with regard to the performance of the company, and this leads to the misleading of financial statements (Balacia, 2008). The widespread corruption in the society and the failure of organizations in every part of the world have once more increased the need for accounting professionals to adhere strictly to the codes of professional practice (Ogbonna and Appah, 2012). This corruption has brought to greater scrutiny the work of the accountant from both within the profession and from outside (Aguolu, 2006). However, (Revsine, 1991); offers some defense for the practice of creative accounting based on positive accounting theory and agency relationship between

\subsubsection{Reasons for Creative Accounting}

Amat (2000), discussed some of the reasons as follows;

- Income smoothing - steady growth is being followed by companies rather than to show volatile profits with a series of dramatic rises and falls. Advocates of this approach argue that it is a measure against the 'short-termism' of judging an investment on the basis of the yields achieved in the immediately following years.

- Matching reported earning to profit forecast: Fox (1997) reports on how accounting policies at Microsoft are designed, within the normal accounting rules, to match reported earnings to profit forecasts. Future potential upgrade and customer support costs sold by Microsoft as a large part of the profit. 
- Changes in accounting method - Company directors may keep an income boosting accounting policy change in hand to distract attention from unwelcome news.

- $\quad$ Boosting the market value of shares - Creative accounting may help maintain or boost the share price both by reducing the apparent levels of borrowing, subject to less risk, and by creating the appearance of a good profit trend. This helps to raise capital from new share issues (Collingwood, 1991), offer the own shares in takeover bids, and resist takeover by other companies.

\subsubsection{Effects of Creative Accounting}

Ijeoma (2014), in his study of the effect of creative accounting on the Nigerian banking industry, concluded that one of the key reasons for creative accounting practice in Nigeria banking industry is to help maintain or boast the share price by reducing the true level of borrowing, making the bank appear less risky for investment and for having good profit trend. Gherai \& Balaciu (2011), observed that a firm that indulge in creative accounting practices is at risk, as its (practices) allows a firm short-term benefit and at the end, such firm is a victim of scandal. Thus, firms loose $30 \%$ of their market value on the average, when financial misrepresentations are publicity disclosed, (Karpoff, Lee \& Martin, 2008). Therefore, whenever the creative accounting behaviours are exposed, the bank loses integrity and the confidence of investors and that of the general public. Existing investors are lost, while there is difficulty in attracting potential (new) investors. Such banks may be distressed and eventually collapsed.

Akenbor \& Ibanichuka (2012), observed that banks involve in a deliberate nondisclosure of information and manipulation of accounting figures to either make the business appear to be more profitable or less profitable for tax purpose. They further observed that Nigerian government has lost over the years, billions of naira in tax revenue under shady hand dealings designed by bank managers to corruptly evade taxes. Therefore, a creative accounting technique targeted by banks towards evading taxes has denied the Nigerian economy the much needed revenue for sustainable growth and development.

Adetoso and Ajiga (2017) are of the view that the Chief Executives and Directors of banks manage investments on behalf of the shareholders for maximum returns, through dividend payouts and capital appreciation. Appreciation in shareholders wealth is measured by the Earning Per Share (EPS). Sadly, bank managers deceive the shareholders by manipulating the EPS above the reality, thereby given the shareholders the false impression that their investments have been growing steadily. The investors are therefore misled into taking wrong investment decisions as they rely on the accounts/Financial statement.

Ijeoma and Aronu (2013) state that creative accounting is intended to mislead users into accepting the picture that preparers of accounts would prefer to see reported. Thus, studies have shown that creative accounting does exist and it occurs for various reasons. Healy and Wahlen (1999) are of the view that the reason for creative accounting include influencing capital market expectations and valuation, to increase management's compensation, to avoid violating contracts written in terms of accounting numbers and to reduce regulatory costs. In shedding light to these reasons, creative accounting, they explained that the use of accounting information by financial analyst and investors to value stocks has created an incentive for managers to manipulate earnings to influence the short-term performance of the stock. The evidence gathered by researchers show that some firms manage earnings for stock market reasons. The frequency of this occurrence has not yet been determined. Some studies show that compensation and lending contracts give an incentive for firms to manage earnings to increases bonuses, improve job security and mitigate potential violation of debt covenants.

Ijeoma and Aronu (2013) are of the view that creative accounting, due to regulatory motivation, is another area where researchers have begun to discover evidence. Studies suggest that regulatory considerations can induce firms to mange earnings. There is very little evidence, though, on the frequency of this behaviour and the effect on regulators investors (Healy and Wahlen, 1999). In his own contribution Osisioma (2006) noted that the early warning signs of Creative Accounting include; Cash flows that are not correlated with earnings; Debtors balances that are not correlated with revenue; Allowances for bad debts that have no correlation with debtors balances; Reserves that are not correlated with balance sheet items; Acquisitions with apparently no business purpose; Earnings that consistently and precisely meet the expectations of analysis.

\subsection{Theoretical Framework}

The theoretical framework of this study is centered on the underlisted theories

\subsubsection{Agency Theory}

The information asymmetry between principals (shareholders) and agent (management) has been highlighted by agency theory. It also finds the influence of audit quality on the financial performance. Linked contracts between the owners of economic resources and managers have been highlighted by the Sarens and Abdolmohammadi (2007). Watts (1998), mentions that auditing is considered as a bonding cost paid by agents to a third party to satisfy the principals' demand for accountability. Importance of ownership and control has been mentioned by Defond (2012). He mentioned that the more divergence in preferences, the more diffused the ownership. Promoting confidence and reinforcing trust in financial information mentioned by Louise (2005). The agent theory shows that an auditor has developed. Principals appoint agents and delegate some decision making authority to them. 


\subsubsection{The Miller-Modigliani Theory}

The Miller - Modigliani theory was propounded by Miller and Modigliani in 1985. The original ideas presented by Modigliani and Miller are very theoretical and assumes conditions that do not fit with the real world e.g. all firms have a constant cash-flow, there exist no taxes and all investors and businesses can borrow and invest to the same risk-free rate. However, Modigliani and Miller's famous theorem (M\&M theorem) has made a great contribution to the field of finance as several authors have further developed their original theory. This has resulted in several attempts to formulate why the proportion of debt financing is positively correlated with the return on equity (Donaldson, 2011). Today, this formula is better known as the leveraging effect.

A firm that chooses to issue some debt by taking a loan, will increase its return on equity since the cost of lending money from a bank is cheaper than "lending" money from the shareholders. It is cheaper due to the fact that long-term debt normally has lower administrative/issuing costs, debt interests are normally tax deductible and the pre-tax interest rate on debt is invariably lower than the required return of shareholders since debt usually demands assets as securities. This implies that an increasing proportion of debt financing, to a lower interest rate than the required return of shareholders, will increase the return on equity and thereby the wealth of the shareholders.

An alternative way of looking at this phenomenon is to consider the weighted average cost of capital (WACC). In connection to the modified version of M\&M proposition with corporate tax, one can derive that an increased proportion of debt financing, to a lower interest rate than the required return of shareholders, will either reduce the cost of capital or increase the return to shareholders (Hall, 2005). In the latter situation, the cost of capital remains constant as the benefits of using cheaper debt is exactly balanced by the increase in the cost of equity. This leaves a net tax advantage with the conclusion that firms should use as much debt as possible. However, the debt interest rate is only lower than the return on equity to a certain point since creditors demand premiums for the risk they take when lending money. The study is anchored on the agency theory. This is based on the premise that in agency theory, a company consists of a set of linked contracts between the owners of economic resources (the principals) and managers (the agents) who are charged with using and controlling these resources. It is stated that in agency theory, agents have more information than principals and this information asymmetry adversely affects the principals' ability to monitor whether or not their interests are being properly served by the agents. This explains the basis of creative accounting where accounting professionals been agents use their knowledge in order to manipulate the figures included in the annual accounts thereby making it difficult or impossible for the principals been the shareholders to actually know or understand wholly the financials of the company.

\subsection{Empirical Review}

Modum, Ugwoke, Onyeanu, Modebe, Kodjo \& Odoh, (2014) studied the effect of creative accounting on audit failure: The case of Manufacturing Companies Quoted on the Nigerian Stock Exchange. The study adopted a survey research method while the Statistical Package for Social Sciences (SPSS 16 package, 2007) to test the hypothesis that: Creative Accounting has a significant positive impact on audit failure in Nigeria. This hypothesis was accepted at $5 \%$ level of significance. It was found that creative accounting practices have a positive significant effect on audit failure. It was therefore, recommended among other things that creative accounting practices should be legislated against and culprits held accountable.

Adetoso and Ajiga (2017) studied creative accounting practices among Nigeria listed commercial banks: curtailing effect of IFRS adoption. Simple random sampling technique was adopted to select the sample size of ten (10) listed commercial banks, out of the fifteen (15) listed in Nigeria Stock Exchange (NSE). The data used for the study was analyzed using quantitative approach through Statistical Package for Social Science (SPSS)- Version 21 software. The formulated hypotheses were tested using Multiple Regression Model method. The study found out that compliance with IFRS recognition, measurement and disclosure requirements each has significant effects on curtailing creative accounting (manipulation of assets and equity values, income and expenses figures and non-timely recognition of losses) practices among Nigeria listed commercial banks. It was therefore recommended that each bank should continue to educate, train and re-train their staff to refresh their knowledge on application of IFRS requirements and on emerging issues on IFRS.

With the help of Z-test, creative accounting practices o Nigerian banks have been analyzed by Akenbor and Ibanichuka (2012). It also helps to improve market value of share. Leyira and Okeoma (2014) studied the impact of creative accounting on organizational effectiveness: A study of manufacturing firms in Nigeria. The study used correlation statistics and revealed a weak evidence of a positive correlation between income smoothing, artificial transaction and market share. The study concluded that many manufacturing firms in Nigeria underperform but practice creative accounting to appear legitimate. It therefore recommended that IFRS should be adopted in Nigeria to eliminate judgment estimation in accounting treatment of certain items.

Idris, Kehinde, Ajemunigbohun and Gabriel (2012) studied the nature, techniques and prevention of creative accounting: empirical evidence from Nigeria. The survey method was adopted while the study was analyzed using the Chisquare statistic in the Predictive Analytic Software (version 19). It was revealed that the practice of creative accounting is always a deliberate attempt to gain undue advantage by management and also to deceive the stakeholders of the firm, by presenting a good view of the financial position of the firm.

Sen and Inanga (2004) studied creative accounting in Bangladesh and global perspectives. The analysis of the study was based on published materials and Expert Opinion Survey. The study found out that the extent of windowdressing of company financial statements in some developing countries has greatly violated all known ethical standards. This study stresses the need for preventing, rather than stopping, the practice in corporate enterprises wherever it exists. The study recommended that forensic accounting be introduced and recognized internationally. National accounting bodies, law courts, and Governments need to adopt strict measures to stop the practice. 
Amat, Blake and Dowds (1999) studied the ethics of creative accounting. The study adopted survey sampling using tables and percentages for analysis and chi square for testing of hypotheses. The study found out that creative accounting offers a formidable challenge to the accounting profession. The problem is an international one, with accounting policy choice being a particular problem in the Anglo American tradition and transaction manipulation a particular problem in the continental European tradition. There is a wide variety of motivations for managers to engage in creative accounting.

Ahmed (2017) studied the impact of creative accounting techniques on the reliability of financial reporting with particular reference to Saudi auditors and academics. Descriptive and inferential statistics were used to generalize the results and conclude the findings. The result deduced that creative accounting techniques used by management negatively affect the reliability of financial reporting. The statutory auditor plays an important role in promoting creative accounting practice in such way that positively affect the reliability of financial reporting.

\section{Methodology}

\subsection{Research Design}

The researcher adopted ex-post facto research design. The choice of the ex-post facto design is because the research relied on already recorded events, and researchers do not have control over the relevant dependent and independent variables they are studying with a view to manipulating them (Onwumere, 2009).

\subsection{Area of the Study}

This research is on the effect of creative accounting on the financial performance of deposit money banks in Nigeria from 2008 to 2017. It will be conducted in Nigeria.

\subsection{Sources of Data}

This study made use of secondary data covering a period of 10 years i.e. 2008 - 2017 and was obtained from the financial statements of deposit money banks in Nigeria that were selected for the study.

\subsection{Population of the Study}

The population of study comprised of all the deposit money banks in Nigerian. There are a total of twenty two

(22) deposit money banks in. They are;

First Bank Nigeria Plc,

Diamond Bank Plc,

Eco Bank Nigeria Plc,

Union Bank Nigeria Plc,

First City Monument Bank (FCMB) Nigeria Plc,

Skye Bank Nigeria Plc,

United Bank for Africa,

Fidelity Bank Nigeria Plc,

Zenith Bank Nigeria Plc,

Citi Bank Nigeria Plc,

Access Bank Nigeria Plc,

Guaranty Trust Bank Nigeria Plc,

Wema Bank Nigeria Plc,

Unity Bank Nigeria Plc,

United Bank Nigeria Plc,

Heritage Bank Nigeria Plc,

Keystone Bank Nigeria Plc,

Sterling Bank Nigeria Plc,

Stanbic IBTC Bank,

Suntrust Bank Nigeria Plc,

Pridus Bank

Standard Chartered Bank

\subsection{Sample Size Determination}

The sample size consists of five (5) selected deposit money banks in Nigeria. They include; Diamond Bank Plc, First Bank Plc, Zenith Bank Plc, United Bank for Africa (UBA) and Guaranty Trust Bank Plc. These banks were sampled with the aid of judgmental sampling. The basis for the selection rests on the fact that these banks have been rated as the top most five Nigerian banks by Fitch rating and Bankers' magazine as at January 2017

\subsection{Model Specification}

The following model will be used to evaluate the study:

PAT $=\mathrm{F}(\mathrm{TA}, \mathrm{TL}, \mathrm{TE})$

Where:

PAT $=$ Profit after Tax 
TA

TL

TE
$=$ Total Assets

$=$ Total Liability

$=$ total Equity

In a linear regression form, it will become:

$\mathrm{PAT}_{\mathrm{it}}=\beta \mathrm{o}+\beta_{1} \mathrm{TA}_{\mathrm{it}}+\beta_{2} \mathrm{TL}_{\mathrm{it}}+\beta_{3} \mathrm{TE}_{\mathrm{it}}+\mu$

$\beta o=$ Constant Term

$\beta_{1}=$ Coefficient of TA

$\beta_{2}=$ Coefficient of TL

$\beta_{3}=$ Coefficient of TE

$\mu=$ Error Term

\subsection{Description of Variables}

\subsubsection{Dependent Variable}

- Profit after Tax: Profit after Tax (PAT) is the net profit earned by the company after deducting all expenses like interest, depreciation and tax. PAT can be fully retained by a company to be used in the business.

- Independent Variable: Total Assets: Total asset is the combined amount of a company's fixed assets and current assets as recorded in the company's balance sheet. This shows all the assets used by a company regardless of how they are financed.

\subsubsection{Total Liability}

Total liabilities are the aggregate debt and financial obligations owed by a business to individuals and organizations at any specific period of time. Total liabilities are reported on a company's balance sheet and are a component of the general accounting equation: Assets =Liabilities + Equity.

\subsubsection{Total Equity}

Total equity is the value left in the company after subtracting total liabilities from total assets. The formula to calculate total equity is Equity = Assets - Liabilities.

\subsection{Analytical Procedure}

Panel data covering a period of 10 years was estimated using diverse techniques, such as descriptive statistics, unit root test and multiple regressions.

\subsection{Decision Rule}

Reject the null hypothesis if the $\mathrm{t}$ - statistics is greater than 2.5 and the P-value is less than $5 \%$, otherwise accept the null hypothesis.

\section{Data Presentation and Analysis}

\subsection{Data Presentation}

Data for the study, sourced from the annual report of the selected banks were presented, tested and analyzed. The data collected were organized and used for testing the hypotheses. From the analysis and results generated, deductions and logical conclusions were obtained.

The abbreviations used to signify the variables of study in all the tables are shown in the appendix. 


\begin{tabular}{|c|c|c|c|c|}
\hline & TA & TL & TE & PAT \\
\hline DIAMOND - 08 & 650891 & 534346 & 116544 & 5171 \\
\hline DIAMOND - 09 & 604361 & 494003 & 110358 & -8174 \\
\hline DIAMOND - 10 & 548402 & 431521 & 116881 & 6522 \\
\hline DIAMOND - 11 & 722965 & 630443 & 92522 & -22187 \\
\hline DIAMOND - 12 & 1059137 & 951820 & 107316 & 23073 \\
\hline DIAMOND - 13 & 1354930 & 1216627 & 138303 & 29754 \\
\hline DIAMOND - 14 & 1750270 & 1544609 & 205660 & 22057 \\
\hline DIAMOND - 15 & 1555183 & 1347106 & 208076 & 3833 \\
\hline DIAMOND - 16 & 1662508 & 1451171 & 1662508 & 1970 \\
\hline DIAMOND - 17 & 1695558 & 1481994 & 1695558 & 869 \\
\hline FIRST BANK - 08 & 1667422 & 1316368 & 351054 & 36074 \\
\hline FIRST BANK - 09 & 1772454 & 1454967 & 317487 & 1275 \\
\hline FIRST BANK - 10 & 1140372 & 5938023 & 7910555 & 97 \\
\hline FIRST BANK - 11 & -601664 & 6177612 & 6707941 & -1156 \\
\hline FIRST BANK - 12 & 2770675 & 2398498 & 372176 & 72132 \\
\hline FIRST BANK - 13 & 3246577 & 2895868 & 350709 & 66452 \\
\hline FIRST BANK - 14 & 3490871 & 3067624 & 423047 & 75175 \\
\hline FIRST BANK - 15 & 3332375 & 2872628 & 459747 & 37 \\
\hline FIRST BANK - 16 & 266903 & 7198 & 261964 & 7507 \\
\hline FIRST BANK - 17 & 269621 & 7657 & 259705 & 9275 \\
\hline ZENITH BANK - 08 & 1680032 & 1341549 & 338483 & 46524 \\
\hline ZENITH BANK - 09 & 1573196 & 1244813 & 328383 & 18365 \\
\hline ZENITH BANK - 10 & 1895027 & 1531466 & 377790 & 44189 \\
\hline ZENITH BANK - 11 & 2309427 & 1929092 & 361242 & 37414 \\
\hline ZENITH BANK - 12 & 2436886 & 1998883 & 438003 & 95803 \\
\hline ZENITH BANK - 13 & 2878693 & 2406071 & 472662 & 83414 \\
\hline ZENITH BANK - 14 & 3423819 & 3203381 & 512707 & 92479 \\
\hline ZENITH BANK - 15 & 3750327 & 2911112 & 546946 & 98784 \\
\hline ZENITH BANK - 16 & 4283736 & 3667383 & 616353 & 119285 \\
\hline ZENITH BANK - 17 & 4833658 & 4126133 & 707525 & 157145 \\
\hline UBA - 08 & 1520091 & 1331936 & 188155 & 40002 \\
\hline UBA - 09 & 1400879 & 1213160 & 187719 & 12889 \\
\hline UBA - 10 & 1432632 & 1244902 & 187730 & 2167 \\
\hline UBA - 11 & 1655465 & 1485407 & 170058 & -16385 \\
\hline UBA - 12 & 1933065 & 1712748 & 220317 & 47375 \\
\hline UBA - 13 & 2217417 & 1957879 & 259538 & 46483 \\
\hline UBA - 14 & 2338858 & 2056925 & 281933 & 40083 \\
\hline UBA - 15 & 2216337 & 1878106 & 338231 & 47642 \\
\hline UBA - 16 & 2539585 & 2148685 & 390900 & 47541 \\
\hline UBA - 17 & 2931826 & 2529311 & 402515 & 42438 \\
\hline GTBANK - 08 & 963118 & 782080 & 181038 & 29913 \\
\hline GTBANK - 09 & 1078177 & 879911 & 198266 & 28603 \\
\hline GTBANK - 10 & 1168052 & 947798 & 220254 & 39604 \\
\hline GTBANK - 11 & 1608652 & 1374644 & 234008 & 51741 \\
\hline GTBANK - 12 & 1620317 & 1333777 & 286539 & 85263 \\
\hline GTBANK - 13 & 1904365 & 1574719 & 329646 & 85545 \\
\hline GTBANK - 14 & 2126608 & 1766696 & 359912 & 89170 \\
\hline GTBANK - 15 & 2277629 & 1872020 & 405608 & 94308 \\
\hline GTBANK - 16 & 2613340 & 2136422 & 476917 & 126836 \\
\hline GTBANK - 17 & 2824928 & 2240584 & 584344 & 161284 \\
\hline
\end{tabular}

Table 1: Table showing the pooled data of Diamond Bank, First Bank, Zenith Bank,

United Bank for Africa and Guaranty Trust Bank

Source: Financial Statement of the selected banks

NB:

TA:

TL:

TE:

PAT:
Total Assets

Total Liability

Total Equity

Profit after Tax 


\begin{tabular}{|c|c|c|c|c|}
\hline & LTA & LTL & LTE & LPAT \\
\hline DIAMOND - 08 & 13.38610 & 13.18880 & 11.66602 & 8.550821 \\
\hline DIAMOND - 09 & 13.31193 & 13.11030 & 11.61148 & 9.008714 \\
\hline DIAMOND - 10 & 13.21476 & 12.97507 & 11.66891 & 8.782936 \\
\hline DIAMOND - 11 & 13.49112 & 13.35418 & 11.43520 & 10.00726 \\
\hline DIAMOND - 12 & 13.87296 & 13.76613 & 11.58353 & 10.04642 \\
\hline DIAMOND - 13 & 14.11926 & 14.01159 & 11.83720 & 10.30072 \\
\hline DIAMOND - 14 & 14.37528 & 14.25028 & 12.23398 & 10.00139 \\
\hline DIAMOND - 15 & 14.25710 & 14.11347 & 12.24566 & 8.251403 \\
\hline DIAMOND - 16 & 14.32384 & 14.18788 & 14.32384 & 7.585789 \\
\hline DIAMOND - 17 & 14.34352 & 14.20890 & 14.34352 & 6.767343 \\
\hline FIRST BANK - 08 & 14.32679 & 14.09039 & 12.76870 & 10.49333 \\
\hline FIRST BANK - 09 & 14.38788 & 14.19049 & 12.66819 & 7.150701 \\
\hline FIRST BANK - 10 & 13.94687 & 15.59689 & 15.88371 & 4.574711 \\
\hline FIRST BANK - 11 & 13.30745 & 15.63644 & 15.71880 & 7.052721 \\
\hline FIRST BANK - 12 & 14.83460 & 14.69035 & 12.82712 & 11.18625 \\
\hline FIRST BANK - 13 & 14.99311 & 14.87880 & 12.76771 & 11.10424 \\
\hline FIRST BANK - 14 & 15.06566 & 14.93641 & 12.95524 & 11.22757 \\
\hline FIRST BANK - 15 & 15.01920 & 14.87074 & 13.03843 & 3.610918 \\
\hline FIRST BANK - 16 & 12.49464 & 8.881558 & 12.47596 & 8.923591 \\
\hline FIRST BANK - 17 & 12.50477 & 8.943376 & 12.46730 & 9.135078 \\
\hline ZENITH BANK - 08 & 14.33432 & 14.10934 & 12.73223 & 10.74772 \\
\hline ZENITH BANK - 09 & 14.26862 & 14.03450 & 12.70194 & 9.818202 \\
\hline ZENITH BANK - 10 & 14.45474 & 14.24174 & 12.84209 & 10.69623 \\
\hline ZENITH BANK - 11 & 14.65251 & 14.47256 & 12.79730 & 10.52980 \\
\hline ZENITH BANK - 12 & 14.70623 & 14.50810 & 12.98998 & 11.47005 \\
\hline ZENITH BANK - 13 & 14.87285 & 14.69351 & 13.06614 & 11.33157 \\
\hline ZENITH BANK - 14 & 15.04627 & 14.97972 & 13.14746 & 11.43474 \\
\hline ZENITH BANK - 15 & 15.13735 & 14.88405 & 13.21211 & 11.50069 \\
\hline ZENITH BANK - 16 & 15.27034 & 15.11499 & 13.33158 & 11.68927 \\
\hline ZENITH BANK - 17 & 15.39111 & 15.23285 & 13.46953 & 11.96492 \\
\hline UBA - 08 & 14.23428 & 14.10214 & 12.14502 & 10.59668 \\
\hline UBA - 09 & 14.15261 & 14.00874 & 12.14270 & 9.464130 \\
\hline UBA - 10 & 14.17502 & 14.03457 & 12.14276 & 7.681099 \\
\hline UBA - 11 & 14.31959 & 14.21120 & 12.04389 & 9.704122 \\
\hline UBA - 12 & 14.47462 & 14.35361 & 12.30282 & 10.76585 \\
\hline UBA - 13 & 14.61185 & 14.48737 & 12.46666 & 10.74684 \\
\hline UBA - 14 & 14.66517 & 14.53672 & 12.54942 & 10.59871 \\
\hline UBA - 15 & 14.61137 & 14.44577 & 12.73148 & 10.77147 \\
\hline UBA - 16 & 14.74751 & 14.58037 & 12.87621 & 10.76935 \\
\hline UBA - 17 & 14.89114 & 14.74346 & 12.90549 & 10.65580 \\
\hline GTBANK - 08 & 13.77793 & 13.56971 & 12.10646 & 10.30605 \\
\hline GTBANK - 09 & 13.89078 & 13.68758 & 12.19736 & 10.26127 \\
\hline GTBANK - 10 & 13.97085 & 13.76190 & 12.30254 & 10.58669 \\
\hline GTBANK - 11 & 14.29091 & 14.13371 & 12.36311 & 10.85401 \\
\hline GTBANK - 12 & 14.29813 & 14.10353 & 12.56563 & 11.35350 \\
\hline GTBANK - 13 & 14.45966 & 14.26959 & 12.70577 & 11.35680 \\
\hline GTBANK - 14 & 14.57004 & 14.38462 & 12.79361 & 11.39830 \\
\hline GTBANK - 15 & 14.63865 & 14.44253 & 12.91314 & 11.45432 \\
\hline GTBANK - 16 & 14.77614 & 14.57464 & 13.07510 & 11.75065 \\
\hline GTBANK - 17 & 14.85399 & 14.62225 & 13.27825 & 11.99092 \\
\hline
\end{tabular}

Table 2: Table Showing the Logs of the Pooled Data of Diamond Bank, First Bank,

Zenith Bank, United Bank for Africa and Guaranty Trust Bank

Source: Eviews 9.0

Table 2 shows the logs of total assets, total liability, total equity and profit after tax of the selected banks under study. These variables were trans-logged to improve the regression result of the study.

\subsection{Data Analysis}

Data analysis depicts how the data collected for each of the banks are analyzed with diverse analytical tools. 


\subsubsection{Descriptive Analysis}

\begin{tabular}{|c|c|c|c|c|}
\hline & Skewness & Kurtosis & Jarque-Bera Stat. & Prob. \\
\hline LTA & -1.003305 & 4.064132 & 10.74763 & 0.004636 \\
\hline LTL & -3.172655 & 14.47023 & 357.9773 & 0.000000 \\
\hline LTE & 1.746965 & 7.296269 & 63.88642 & 0.000000 \\
\hline LPAT & -1.647363 & 5.706885 & 37.88011 & 0.000000 \\
\hline
\end{tabular}

Table 3: Description of the Characteristics of the Variables under

Study for the pooled data of Diamond Bank, First Bank, Zenith Bank, United Bankfor Africa and Guaranty Trust Bank Source: Author's Computation from Eviews 9.0

Table 3 contains the description of the variables using normality test which comprises of Skewness, Kurtosis and Jarque - Bera Statistics. The table showed that the logs of total assets, total liability and profit after tax were negatively skewed relative to normal while the log of total equity was positively skewed relative to normal.

The table also showed that all the variables were leptokurtic as their kurtosis values are greater than three (3).

The table also showed that all the variables are normally distributed as the probability values of their Jarque-Bera statistics are less than 0.05 .

\subsubsection{Unit Root Test}

This test tries to examine the property of the variables. It is used to check for the presence of a unit root i.e. whether the variables are stationary. This test is carried out using the Augmented Dickey Fuller (ADF) test. The ADF is carried out using E-views software package and the results from the test are tabulated below:

\begin{tabular}{|c|c|c|c|c|c|c|}
\hline & \multicolumn{2}{|c|}{ LLC } & \multicolumn{2}{|c|}{ ADF - FISHER } & \multicolumn{2}{|c|}{ PP - FISHER } \\
\hline & Test Stat. & $\begin{array}{c}\text { Order of } \\
\text { integration }\end{array}$ & Test Stat. & $\begin{array}{c}\text { Order of } \\
\text { integration }\end{array}$ & Test Stat. & $\begin{array}{c}\text { Order of } \\
\text { integration }\end{array}$ \\
\hline LTA & $\begin{array}{c}-3.79 \\
(0.0001<0.05)\end{array}$ & $\mathrm{I}(\mathrm{I})$ & $\begin{array}{c}18.57 \\
(0.049<0.05)\end{array}$ & I(I) & $\begin{array}{c}53.50 \\
(0.0000<0.05)\end{array}$ & I(I) \\
\hline LTL & $\begin{array}{c}-3.56 \\
(0.0002<0.05)\end{array}$ & $\mathrm{I}(\mathrm{I})$ & - & - & $\begin{array}{c}19.24 \\
(0.0038<0.05)\end{array}$ & I(I) \\
\hline LTE & $\begin{array}{c}-2.86 \\
(0.0021<0.05)\end{array}$ & $\mathrm{I}(\mathrm{I})$ & $\begin{array}{c}15.80 \\
(0.0149<0.05)\end{array}$ & $\mathrm{I}(\mathrm{I})$ & $\begin{array}{c}36.45 \\
(0.0000<0.05)\end{array}$ & I (I) \\
\hline LPAT & $\begin{array}{c}-2.67 \\
(0.0038<0.05)\end{array}$ & $\mathrm{I}(\mathrm{I})$ & $\begin{array}{c}13.05 \\
(0.0423<0.05)\end{array}$ & $\mathrm{I}(\mathrm{I})$ & $\begin{array}{c}15.01 \\
(0.0202<0.05)\end{array}$ & $\mathrm{I}(\mathrm{I})$ \\
\hline
\end{tabular}

Table 4: Pooled Unit Root Test for Diamond Bank, First Bank, Zenith Bank, United Bank for Africa and Guaranty Trust Bank Source: Author's Compilation from Eviews 9

LLC = Levin, Lin and Chu Test

IPS = Im, Pesaran and Shin W - Stat

ADF FISHER = Augmented Dickey Fuller Fisher Chi - Square Test

PP FISHER = Philip Peron Fisher Chi - Square Test

Table 4 showed that all the variables are integrated of order one or are stationary at first difference.

\subsection{Test of Hypotheses}

The test of hypothesis was carried out as follows:

Step 1: Re-statement of the hypothesis in the null and alternate forms

Step 2: Statement of decision criteria

Step 3: Presentation of test result

Step 4: Decision

\subsubsection{Test of Hypothesis One}

4.3.1.1. Step 1: Restatement of the Hypothesis

- $\mathrm{H}_{01}$ : Creative accounting in assets does not have positive and significant effect on the profit after tax of deposit money banks in Nigeria.

4.3.1.2. Step 2: Statement of Decision Criteria

Reject $\mathrm{H}_{0}$ if the t-statistics is $>2.5$ and the probability of the t-statistics is $<0.05$. 


\subsubsection{Step 3: Presentation of test result}

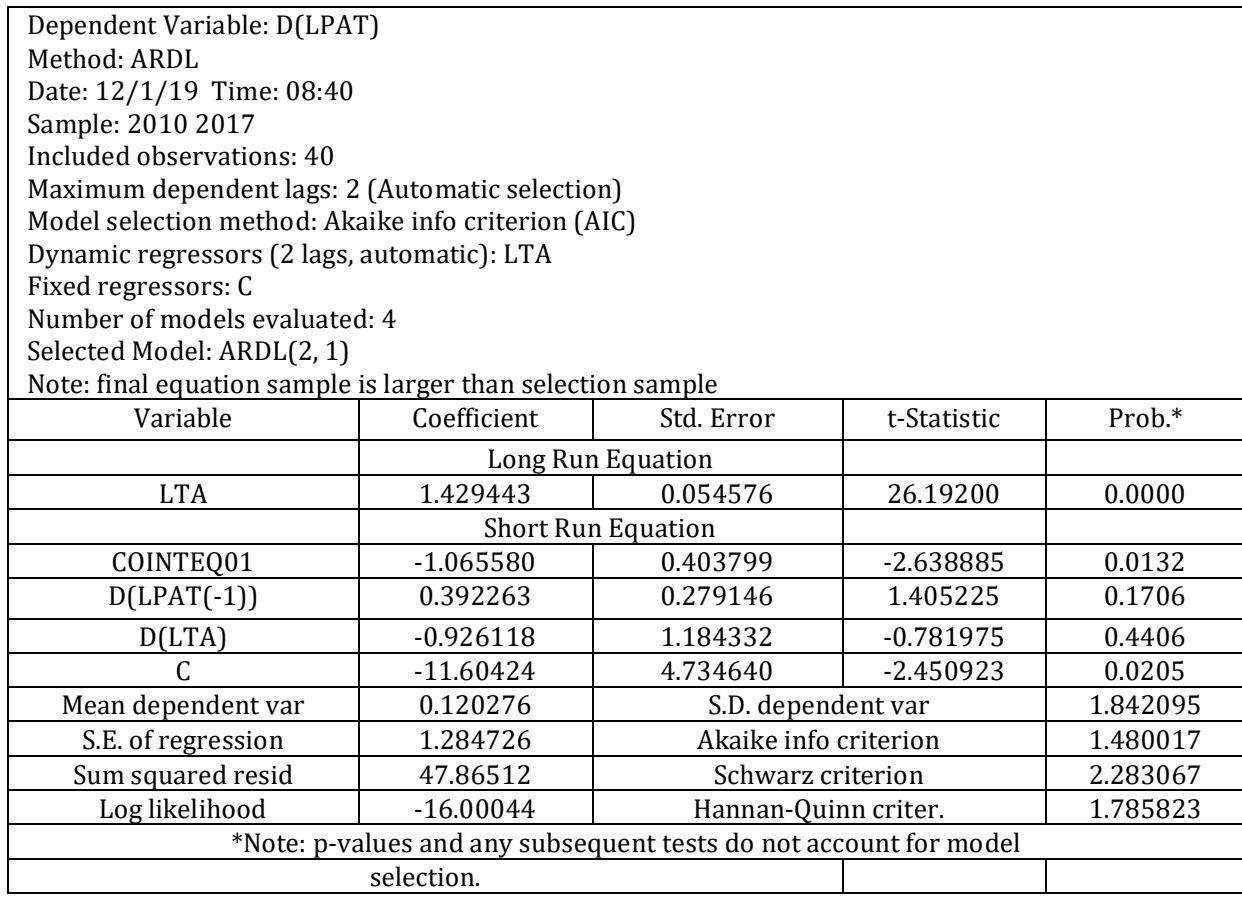

Table 5: Test of Hypothesis One

Source: Author's Computation from E-View 9.0

4.3.1.4. Step 4: Decision

Given the decision criteria to reject $\mathrm{H}_{0}$ if the $\mathrm{t}$-statistics is $>2.5$ and the probability of the $\mathrm{t}$-statistics is $<0.05$. Table 4.4 .1 showed the t-statistics of LTA as $26.19200>2.5$ with a probability of the t-statistics of $0.0000<0.05$. We reject the null hypothesis (H0) and conclude that creative accounting in assets has positive and significant effect on the profit after tax of deposit money banks in Nigeria.

\subsubsection{Test of Hypothesis Two}

4.3.2.1. Step 1: Restatement of the hypothesis

- Ho2: Creative accounting in liabilities does not positively and significantly affect the profit after tax of deposit money banks in Nigeria.

4.3.2.2. Step 2: Statement of Decision Criteria

Reject $\mathrm{H}_{\mathrm{O}}$ if the $\mathrm{t}$-statistics is $>2.5$ and the probability of the $\mathrm{t}$-statistics is $<0.05$.

4.3.2.3. Step 3: Presentation of Test Result

\begin{tabular}{|c|c|c|c|c|}
\hline \multicolumn{5}{|c|}{$\begin{array}{l}\text { Dependent Variable: D(LPAT) } \\
\text { Method: ARDL } \\
\text { Date: } 12 / 1 / 19 \text { Time: } 08: 44 \\
\text { Sample: } 20102017 \\
\text { Included observations: } 40 \\
\text { Maximum dependent lags: } 2 \text { (Automatic selection) } \\
\text { Model selection method: Akaike info criterion (AIC) } \\
\text { Dynamic regressors (2 lags, automatic): LTL } \\
\text { Fixed regressors: C } \\
\text { Number of models evaluated: } 4 \\
\text { Selected Model: ARDL(2, } 2 \text { ) } \\
\text { Note: final equation sample is larger than selection sample }\end{array}$} \\
\hline \multirow[t]{2}{*}{ Variable } & Coefficient & Std. Error & t-Statistic & Prob.* \\
\hline & \multicolumn{2}{|l|}{ Long Run Equation } & & \\
\hline \multirow[t]{2}{*}{ LTL } & 1.432960 & 0.059824 & 23.95293 & 0.0000 \\
\hline & \multicolumn{2}{|l|}{ Short Run Equation } & & \\
\hline COINTEQ01 & -0.850329 & 0.264279 & -3.217544 & 0.0037 \\
\hline D(LPAT(-1)) & 0.267661 & 0.127196 & 2.104323 & 0.0460 \\
\hline $\mathrm{D}(\mathrm{LTL})$ & -0.445416 & 0.980114 & -0.454453 & 0.6536 \\
\hline D(LTL(-1)) & -0.273961 & 0.833360 & -0.328742 & 0.7452 \\
\hline $\mathrm{C}$ & -9.111601 & 2.863969 & -3.181459 & 0.0040 \\
\hline Mean dependent var & 0.120276 & \multicolumn{2}{|c|}{ S.D. dependent var } & 1.842095 \\
\hline S.E. of regression & 1.236188 & \multicolumn{2}{|c|}{ Akaike info criterion } & 1.535680 \\
\hline Sum squared resid & 36.67587 & \multicolumn{2}{|c|}{ Schwarz criterion } & 2.529932 \\
\hline Log likelihood & -12.39200 & \multicolumn{2}{|c|}{ Hannan-Quinn criter. } & 1.914297 \\
\hline
\end{tabular}

Table 6: Test of Hypothesis Two

Source: Author's Computation from E-View 9.0 


\subsubsection{Step 4: Decision}

Given the decision criteria to reject $\mathrm{H}_{0}$ if the t-statistics is $>2.5$ and the probability of the t-statistics is $<0.05$. Table 4.4.1 shows the t-statistics of LTL as $23.95293>2.5$ with a probability of the t-statistics of $0.0000<0.05$. We reject the null hypothesis ( $\mathrm{HO}$ ) and conclude that creative accounting in liabilities positively and significantly affect the profit after tax of deposit money banks in Nigeria.

\subsubsection{Test of Hypothesis Three}

4.3.3.1. Step 1: Restatement of the hypothesis.

$\mathrm{H}_{03}$ : A significant relationship does not exist between creative accounting in equity and profit after tax of deposit money banks in Nigeria.

\subsubsection{Step 2: Statement of Decision Criteria}

Reject $\mathrm{H}_{0}$ if the t-statistics is $>2.5$ and the probability of the t-statistics is $<0.05$.

\subsubsection{Step 3: Presentation of Test Result}

\begin{tabular}{|c|c|c|c|c|}
\hline \multicolumn{5}{|c|}{ Dependent Variable: D(LPAT) } \\
\hline \multicolumn{5}{|l|}{ Method: ARDL } \\
\hline \multicolumn{5}{|c|}{ Date: $12 / 1 / 19$ Time: $08: 46$} \\
\hline \multicolumn{5}{|l|}{ Sample: 20102017} \\
\hline \multicolumn{5}{|c|}{ Included observations: 40} \\
\hline \multicolumn{5}{|c|}{ Maximum dependent lags: 2 (Automatic selection) } \\
\hline \multicolumn{5}{|c|}{ Model selection method: Akaike info criterion (AIC) } \\
\hline \multicolumn{5}{|c|}{ Dynamic regressors (2 lags, automatic): LTE } \\
\hline \multicolumn{5}{|l|}{ Fixed regressors: C } \\
\hline \multicolumn{5}{|c|}{ Number of models evaluated: 4} \\
\hline \multicolumn{5}{|c|}{ Selected Model: ARDL(1, 2) } \\
\hline \multicolumn{5}{|c|}{ Note: final equation sample is larger than selection sample } \\
\hline \multirow[t]{2}{*}{ Variable } & Coefficient & Std. Error & t-Statistic & Prob.* \\
\hline & \multicolumn{4}{|c|}{ Long Run Equation } \\
\hline \multirow[t]{2}{*}{ LTE } & 0.878585 & 0.197117 & 4.457170 & 0.0001 \\
\hline & \multicolumn{2}{|c|}{ Short Run Equation } & & \\
\hline COINTEQ01 & -0.851160 & 0.315327 & -2.699294 & 0.0115 \\
\hline $\mathrm{D}(\mathrm{LTE})$ & 2.298023 & 1.892865 & 1.214045 & 0.2345 \\
\hline D(LTE $(-1))$ & 0.362805 & 1.535472 & 0.236282 & 0.8149 \\
\hline $\mathrm{C}$ & -1.410366 & 0.820768 & -1.718350 & 0.0964 \\
\hline Mean dependent var & 0.120276 & \multicolumn{2}{|c|}{ S.D. dependent var } & 1.842095 \\
\hline S.E. of regression & 1.154651 & \multicolumn{2}{|c|}{ Akaike info criterion } & 1.131544 \\
\hline Sum squared resid & 38.66332 & \multicolumn{2}{|c|}{ Schwarz criterion } & 1.934594 \\
\hline Log likelihood & -7.288605 & \multicolumn{2}{|c|}{ Hannan-Quinn criter. } & 1.437350 \\
\hline \multicolumn{5}{|c|}{ *Note: p-values and any subsequent tests do not account for model } \\
\hline \multicolumn{3}{|l|}{ selection. } & & \\
\hline
\end{tabular}

\subsection{Discussion of Result}

Source: Author's Computation from E-View 9.0

The following results were generated from the analysis of study;

\subsubsection{Discussion of Hypothesis One}

Creative accounting in assets has positive and significant effect on the profit after tax of deposit money banks in Nigeria based on the premise that the t-statistics of LTA been 26.19200 was greater than 2.5 while the probability value been 0.0000 was less than 0.05 . The study is in agreement with the assertion of Adetoso and Ajiga (2017) who studied creative accounting practices among Nigeria listed commercial banks: curtailing effect of IFRS adoption. The study found out that compliance with IFRS recognition, measurement and disclosure requirements each has significant effects on curtailing creative accounting (manipulation of assets and equity values, income and expenses figures and non-timely recognition of losses) practices among Nigeria listed commercial banks.

\subsubsection{Discussion of Hypothesis Two}

Creative accounting in liabilities positively and significantly affect the profit after tax of deposit money banks in Nigeria due to the fact that the t-statistics of LTL been 23.95293 was greater than 2.5 while the probability value been 0.0000 was less than 0.05 . This discovery agreed with the findings of Akenbor and Ibanichuka (2012) who studied creative 
accounting practices in Nigerian banks. The study found out that the major reason for creative accounting practices in Nigerian banks is to boost the market value of shares.

\subsubsection{Discussion of Hypothesis Three}

A significant relationship exist between creative accounting in equity and profit after tax of deposit money banks in Nigeria as the t-statistics of LTE been 4.457170 was greater than 2.5 while the probability value been 0.0001 was less than 0.05. The discovery agreed with the findings of Shawar and Qaisar (2015) who studied Creative Accounting: Developing a Model. The study found out that the definitive purpose behind creative accounting is the exploitation of financial outcomes to safeguard certain interests.

\section{Summary of Findings, Conclusion and Contribution to Knowledge}

\subsection{Findings}

The summary of findings for this study includes the following:

- Nigerian banks have positive and significant effect on the profit after tax and creative accounting.

- Positive and significant relationship has been observed between the profit after tax and Creative accounting.

- Creative accounting in equity and profit after tax has significant relationship for deposit money banks in Nigeria.

\subsection{Conclusion}

This study examines the relationship between creative accounting in equity and profit after tax of deposit money banks in Nigeria. These objectives guided the study which led to the formulation of research questions and hypotheses that were analyzed and tested in the chapter four of the study. The study was reviewed by focusing on concepts, theories and empirical literatures which concluded by tabulating a summary of the empirical literatures and establishing a gap in literature. The study adopted ex post facto design and focused on the banking sector while using descriptive statistics, unit root test and multiple regressions as analytical tools to arrive at the findings that creative accounting in assets, liabilities and equities have positive and significant effect on the profit after tax of deposit money banks in Nigeria.

\subsection{Contribution to Knowledge}

The study contributed immensely to diverse reasons why some companies engage in creative accounting such as Income smoothing, matching reported earning to profit forecast, changes in accounting method, boosting the market value of shares, delaying market information.

The study equally contributed to immense knowledge on the essence of creative accounting practice in Nigeria banking industry which is to help maintain or boast the share price by reducing the true level of borrowing, making the bank appear less risky for investment and for having good profit trend.

\section{References}

i. Adetoso, J.A and Ajiga, O. F. (2017). Creative Accounting Practices among Nigeria Listed Commercial Banks: Curtailing Effect of IFRS Adoption, Journal of Resources Development and Management, 38 (54), 12 - 19.

ii. Ahmed, Y. A. (2017). The Impact of Creative Accounting Techniques on the Reliability of Financial Reporting with Particular Reference to Saudi Auditors and Academics, International Journal of Economics and Financial Issues, $7(2), 283-291$.

iii. Akenbor, C. O. and Ibanichuka, E. A. L. (2012). Creative Accounting Practices in Nigerian Banks, An International Multidisciplinary Journal, Ethiopia, 6 (3), 26 - 33.

iv. Balacia, O. (2008), Is Creative Accounting a form of Manipulation? Vol. 111. Section. Fainter. Oradea: Bonci Contrabiliate Tom. pXVII

v. Balaciu, D., Bogdan, V. and Vladu, A. B. (2009). A Brief Review of Creative Accounting Literature and its Consequences in Practice. Annales Universitatis Apulensis Series Oeconomica, 11(1), 28 - 32.

vi. Balaciu, D. E., Bogdan, V., Mester, L. T. and Gherai, D. (2012). Empirical Evidences of Romanian Auditors' Behavior regarding Creative Accounting Practices, Accounting and Management Information Systems, 11 (2), 213 - 238.

vii. Beshiru, S., Prince, F.I. (2014), Nigerian commercial banks and creative accounting practices. Journal of Mathematical Finance, 4(19), 75 - 83.

viii. Collingwood, H (1991). Why K-Mart's Goodnews isn't; Business Week; March; 40 Defond, M. L. (2012). The association between changes in client firm agency costs and auditor switching. Journal of Auditing Practice and Theory, 11 (1), $22-28$.

ix. Dharan, B. and Lev, B. (1993). The valuation consequence of accounting charges: a multi- year examination, Journal of Accounting Auditing and finance, 8 (4): 475-494.

x. Donaldson, L. (2011). Corporate governance, directors' and officers' insurance premiums and audit fees. Managerial Auditing Journal, 29(2), 173-195.

xi. Ezeani, N. S. (2010). Impact of Audit Report on the job performance of Accountants in the public Sector $10-13$. Unpublished

xii. Friedlander, F., and Pickle, H. (1968). Components of effectiveness in small organizations. Administrative Science Quarterly, 13(7), 289 - 304.

xiii. Gherai, D.S. and Balaciu, D.E. (2011), From creative accounting practices and enron phenomenon to the current financial crisis. Annales Universitatis Apulensis Series Oeconomica, 13(1), 34-41 
xiv. Hall, A. U. (2005). The effect of audit firm size on audit prices: A study of the Australian market. Journal of accounting and Economics, 6(2), 133-151.

xv. Healy, P.M. and Wahlen, J.M. (1999). A Review of the Earnings Management Literature and its Implications for Standard Setting. Accounting Horizons, 12 (6), 65 - 83.

xvi. Idris, A. A., Kehinde, J. S., Ajemunigbohun, S. S. and Gabriel, J. M. O. (2012). The Nature, Techniques and Prevention of Creative Accounting: Empirical Evidence from Nigeria, eCanadian Journal of Accounting and Finance, 1 (1), 26 31.

xvii. Ijeoma, N.B. (2014). The effect of creative accounting on the Nigerian banking industry. International Journal of Managerial Studies and Research, 2(10). 13-21.

xviii. Ijeoma, N. and Aronu, C. O. (2013). The Contribution of Creative Accounting on Economic Development, International Journal of Scientific \& Engineering Research, 4 (9), 12 - 18.

xix. Imoisili, C.I. (1978). Key success factor in multinational and indigenous companies in Nigeria. A comparative Analysis, Columbia Journal of World business Fall. 12 (9), 40 - 53.

xx. Karpoffa, J. M., Lee, D. S. and Martin, G. S. 0. The consequences to managers for financial misrepresentation, Journal of Financial Economics, 18 (28), 33-44

xxi. Leyira, C. M. and Okeoma, E. C. (2014). The Impact of Creative Accounting on Organizational Effectiveness: A Study of Manufacturing Firms in Nigeria, British Journal of Economics, Management \& Trade, 4(12), 21 - 28.

xxii. Louise, M. (2005).The effects of auditor independence on audit quality. Paper presented the Department of Accounting, Bowling Green State University.

xxiii. Modum, U., Ugwoke, R. O, Onyeanu, E. O, Modebe, N. J. Kodjo, S. N \& Odoh, I.

xxiv. C. (2014). The Effect of Creative Accounting on Audit Failure: The Case of Manufacturing Companies Quoted on the Nigerian Stock Exchange, Journal of accounting and Finance, 1 (3), 9 - 11.

xxv. Ndebugri, H. and Senzu, E. T. (2017). Analyzing the Critical Effect of Creative Accounting Practice in the Corporate Sector of Ghana, Munich Personal RePEc Archive (MPRA), 12 (9), 27 - 33.

xxvi. Ogbonna, G.N., Appah, E. (2012), The Effect of Ethical Accounting Standards on the Quality of Financial Reports of Banks in Nigeria, Journal of accounting and Economics, 11 (9), 18 - 22.

xxvii. Onoja, E. E. \& Adaaja, O. E. (2015). The Effects of Creative Accounting and its Burden on Auditors' Responsibilities in Nigeria, Journal of Good Governance and Sustainable Development in Africa (JGGSDA), 2(6), 16 - 22.

xxviii. Osisioma B.C. (2006). Fraud Management and Forensic Accounting, Enugu: El-Demak, Inc

xxix. Radu, V. (2013), The impact of creative accounting on financial audit, Studia Universitatis "Vasile Goldiş" Arad. Economics Series, 23(4), 56-62.

xxx. Richard, P. J., Devinney, T., Yip, G. and Johnson, G. (2009). Measuring organizational performance: Towards methodological best practice. Journal of Management, 35 (3), 1 - 3.

xxxi. Sarens, G. \&Abdolmohhamadi, M. J. (2007). Agency theory as a predictor of the size of the internal audit function in Belgian Companies. Paper presented at the Annual Congress of European Accounting Association in Lisbon.

xxxii. Sen, D. K. and Inanga, E. L. (2004) Creative Accounting in Bangladesh and Global Perspectives, Netherlands, Maastricht School of Management,

xxxiii. Shawar, K. D. and Qaisar, M. A. (2015). Creative Accounting: Developing A Model, Research Journal of Recent Sciences, 4(11), $146-150$

xxxiv. Tassadaq, F. and Malik, Q. A. (2015). Creative Accounting and Financial Reporting: Model Development and Empirical Testing, International Journal of Economics and Financial Issues, 5(2), 544 - 551.

xxxv. Uzonwanne, M. C. (2015). Deposit Money Banks and Financing of Small and Medium Scale Enterprises in Nigeria, Journal of Economics and Sustainable Development, 6 (8), 12 - 14.

xxxvi. Victoria, F. (2014), An empirical study on the impact of creative accounting policies on the performance of listed Romanian companies. Valahian Journal of Economic Studies, 5(4), 41-48.

xxxvii. Voinea, M.M. (2013), Accountability represent are normative a really economic? A.I. Cuza University. Intercultural Management, 15(2), 28-37

xxxviii. Watts, L. and Zimmerman, J. (1978). Towards a positive theory of the determination of accounting standards, The Accounting Review, 17 (11), 15 - 19.

xxxix. Yoon, S. S. and Miller, G.A. (2002). Cash from operation and earnings management in Korea. The International Journal of Accounting, 37(4), 395 - 412. 